\section{Khakiweed (Alternanthera pungens Kunth) Growth Response to Mowing Height and Frequency}

\author{
Andrew J. Hephner, Tyler Cooper, and Leslie L. Beck \\ Department of Plant and Soil Science, Texas Tech University, Box 42122, \\ Lubbock, TX 79409
}

\author{
Gerald M. Henry ${ }^{1}$ \\ Department of Crop and Soil Sciences, University of Georgia, 3111 Miller \\ Plant Sciences Building, Athens, GA 30602
}

Additional index words. competition, golf course, turfgrass

\begin{abstract}
The effect of mowing regimens on lateral spread of khakiweed (Alternanthera pungens Kunth) was determined through field studies conducted over a 3-month period in Texas during 2009 and 2010. Treatments were selected to simulate mowing regimens common to intensively managed common bermudagrass [Cynodon dactylon (L.) Pers.] turf and included heights of $1.3 \mathrm{~cm}$ (three times/wk), $2.5 \mathrm{~cm}$ (two times/week), and $5.1 \mathrm{~cm}$ (two times/week). A non-mowed control was included for comparison. Differences in lateral spread of khakiweed among mowing regimens were apparent 4 weeks after initial treatment (WAIT). However, plant diameter increased for all mowing regimens over the course of the trial. Khakiweed plants subjected to the $1.3-\mathrm{cm}$ mowing regimen did not increase in diameter from Week 2 through Week 12, whereas the other two mowing regimens exhibited steady increases in plant diameter over the same time period. By 12 WAIT, non-mowed control plots measured $80.8 \mathrm{~cm}$ in diameter, whereas those maintained at $1.3 \mathrm{~cm}$ measured $55.3 \mathrm{~cm}$. Comparatively, plants subjected to the 2.5 - and 5.1-cm mowing regimens measured 64.7 and $68.8 \mathrm{~cm}$, respectively. Therefore, khakiweed infestations may be more prevalent in bermudagrass mowing heights commonly used for golf course roughs, athletic fields, and home lawns $(2.5 \mathrm{~cm}$ or greater). However, the production of a thick taproot high in carbohydrate content may enable khakiweed to regenerate from frequent defoliation common to fairway mowing regimes $(2.5 \mathrm{~cm}$ or less). Adjustments in mowing height may not be enough to effectively reduce khakiweed populations in bermudagrass turf.
\end{abstract}

Khakiweed (Alternanthera pungens Kunth) has been described as one of the fastest growing weed problems in semiarid and arid environments (Kopec et al., 2004). Common to the southern United States (McCarty et al., 2008), this perennial broadleaf weed spreads through seed production or dissemination of root and stem fragments (Parsons and Cuthbertson, 2001). Infestations are often associated with areas of heavy traffic and wear (e.g., cart paths, athletic fields). Environmental adaptation and unique morphological features have further led to an increase in khakiweed occurrence within desirable turfgrasses, which may lead to long-term reductions in turfgrass density (Sholedice and Renz, 2006; Umeda and Towers, 2004). A thick waxy cuticle and a deep taproot help khakiweed survive acute drought conditions (Parsons

Received for publication 27 Dec. 2011. Accepted for publication 21 Aug. 2013.

We acknowledge the cooperation of Travis Williams, Aaron Holbrook, and Jeremy Rotramel for their technical assistance in this project. Appreciation is also extended to Mike Painter, superintendent at Meadowbrook Golf Course in Lubbock, TX, for providing the khakiweed plants.

${ }^{1}$ To whom reprint requests should be addressed; e-mail gmhenry@uga.edu. and Cuthbertson, 2001) and may contribute to soil salinity tolerance. Infestations often interfere with aesthetic and functional turfgrass quality.

Trifloxysulfuron is the only post-emergence herbicide labeled for the control of khakiweed in warm-season turf (Anonymous, 2009). Kopec et al. (2004) reported 95\%, 94\%, and 98\% khakiweed control $40 \mathrm{~d}$ after treatment (DAT) with trifloxysulfuron applied at 0.017 , 0.029 , and $0.053 \mathrm{~kg}$ a.i./ha, respectively. Athletic field managers and golf course superintendents have also used metsulfuron for khakiweed control. Kopec et al. (2004) observed $99 \%$ khakiweed control 40 DAT with single applications of metsulfuron at 0.021 or $0.042 \mathrm{~kg}$ a.i./ha. Umeda (2008) observed 86\% khakiweed control $36 \mathrm{~d}$ after initial treatment with applications of carfentrazone $+2,4-\mathrm{D}+$ mecoprop + dicamba at $0.45 \mathrm{~kg}$ a.i./ha. Khakiweed often regenerates from initial herbicide defoliation, so sequential applications may be necessary for adequate control (Hephner et al., 2012; Umeda, 2008). Hephner et al. (2012) reported $95 \%$ to $97 \%$ khakiweed control 12 weeks after treatment in response to sequential applications of metsulfuron at 0.021 or $0.042 \mathrm{~kg}$ a.i./ha, whereas $75 \%$ to $80 \%$ control was observed after sequential applications of trifloxysulfuron at 0.018 or $0.028 \mathrm{~kg}$ a.i./ha.
Few labeled herbicides coupled with sporadic long-term control suggest further examination into the ecology of khakiweed for clues to improved cultural management.

Environmental stewardship, overreliance on chemical control, and increasing concerns about pesticide resistance have led turfgrass managers to examine cultural practices such as mowing to reduce weed populations (Busey, 2003). Previous research suggests that mowing turfgrass infrequently at higher heights will increase weed infestations, whereas more frequent mowing at shorter heights will stress desired turfgrass stands making them more susceptible to weed invasion. Voigt et al. (2001) noted that mowing tall fescue (Festuca arundinacea Schreb.) at $2.5 \mathrm{~cm}$ resulted in $37 \%$ crabgrass (Digitaria spp.) cover, whereas plots mowed at 5.1 and $7.6 \mathrm{~cm}$ resulted in $0 \%$ to $8 \%$ crabgrass cover. Increased smooth crabgrass [Digitaria ischaemum (Schreb.) Muhl.] infestation has been observed in Chewings fescue \{Festuca rubra var. commutate Gaudin $[=F$. rubra subsp. Fallaz (Thuill.) Nyman] $\}$ and tall fescue maintained at lower heights of cut $(2.5 \mathrm{~cm})$ (Dernoeden et al., 1993; Jagschitz and Ebdon, 1985). Similarly, Hoyle (2009) observed a 93\% increase in large crabgrass (Digitaria sanguinalis L.) pressure in tall fescue when mowing height decreased from 10.2 to $2.5 \mathrm{~cm}$. Annual bluegrass (Poa annua L.) infestations increased from $9 \%$ to $34 \%$ as perennial ryegrass (Lolium perenne L.) mowing height dropped from 7.5 to $1.3 \mathrm{~cm}$ (Adams, 1980), whereas reducing carpetgrass $\{$ Axonopus affinis Chase $[=$ A. fissifolius (Raddi) Kuhlm. $]\}$ mowing height from 7.6 to $3.8 \mathrm{~cm}$ increased annual bluegrass infestation from $9 \%$ to $31 \%$ (Bush et al., 2000). However, mowing bermudagrass at $1.3 \mathrm{~cm}$ or less often limits weed encroachment through the formation of a dense canopy (McCarty, 1991), whereas higher heights of cut $(2.5 \mathrm{~cm}$ or greater) may provide openings in the canopy that contribute to weed infestation (Duble, 2001).

Mowing height and frequency may have a greater impact on perennial weeds where reproduction is heavily dependent on vegetative propagation. Reductions in aboveground biomass may cause decreased photosynthetic capability leading to the long-term reduction in carbohydrate accumulation in perennial organs (Stoll et al., 1998). Resources are often reallocated to the regeneration of leaves at the expense of stolon production and extension (Wilen and Holt, 1996). Summerlin et al. (2000) observed decreases in purple nutsedge (Cyperus rotundus L.) rhizome length $(45 \%$ and $82 \%)$ and tuber size ( $7 \%$ and $19 \%)$ when mowed at $3.8 \mathrm{~cm}$ (one time/week) and $1.3 \mathrm{~cm}$ (three times/week), respectively, compared with a non-mowed control. Mowing green kyllinga (Kyllinga brevifolia Rottb.) at $1.3 \mathrm{~cm}$ reduced shoot number and plant spread $52 \%$ and $32 \%$, respectively, whereas mowing at $3.8 \mathrm{~cm}$ resulted in reductions of $0 \%$ and $13 \%$, respectively (Summerlin et al., 2000). Henry et al. (2007) observed significant $(30 \%$ to $57 \%$ ) reductions in the fresh weight of dallisgrass (Paspalum dilatatum Poir.) rhizomes at 
mowing heights of $7.6 \mathrm{~cm}$ (two times/week) to $1.3 \mathrm{~cm}$ (three times/week). Similar reductions $(24 \%$ to $73 \%)$ were reported for bahiagrass (Paspalum notatum Fluegge) as well (Henry et al., 2007). Plant extension of kikuyugrass stolons measured 88,82 , and $71 \mathrm{~cm}$ in response to no mowing, $5.0 \mathrm{~cm}$ (one time/week), and $2.5 \mathrm{~cm}$ (one time/week), respectively (Wilen and Holt, 1996). Although close mowing often discourages the presence of some perennial weeds, added stress to desired turfgrass stands may give weeds a competitive edge. Therefore, desired turfgrass species and weed infestations must be considered when selecting a proper mowing height and frequency. Little published research has examined the effect of mowing height and frequency on the growth of khakiweed. Therefore, the objective of this study was to evaluate the lateral spread of khakiweed in response to mowing heights and frequencies commonly used when managing common bermudagrass [Cynodon dactylon (L.) Pers.].

\section{Materials and Methods}

Experiments were conducted during the summer and fall of 2009 and 2010 at the Quaker Research Farm in Lubbock, TX, on a Brownfield Sandy Clay Loam (loamy, mixed, superactive, thermic Arenic Aridic Paleustalfs) with a $\mathrm{pH}$ of 8.2 and organic matter content of $1.3 \%$. Khakiweed plants were removed from naturally occurring populations present in a common bermudagrass rough at Meadowbrook Golf Course in Lub-

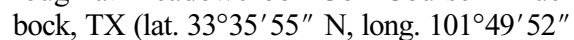
$\mathrm{W})$ maintained at a height of $2.5 \mathrm{~cm}$. A golf course cup cutter centered over each plant was used to remove the aboveground biomass and corresponding taproot together as a $10.2-\mathrm{cm}$ wide plug (leaves/stems were trimmed by the perimeter of the cup cutter) to a depth of $12.7 \mathrm{~cm}$. Plants were transplanted on 15 June 2009 and 14 June 2010 into bare ground by removing a core of soil and replacing it with a khakiweed plug $(10.2 \mathrm{~cm}$ in diameter). Fertilizer (Griggs Brothers 7-7-7 Seven Iron, Albion, ID) was applied to each study area at the time of transplant at a rate of $37 \mathrm{~kg} \cdot \mathrm{ha}^{-1}$ nitrogen $(\mathrm{N})$ with a cyclone spreader (Lesco 80-lb Rotary Broadcast Lawn Spreader; John Deere Landscapes, Troy, MI). Monthly applications of fertilizer (Griggs Brothers 16-4-8 Turf Rally) were made throughout the duration of the study at a rate of $49 \mathrm{~kg} \cdot \mathrm{ha}^{-1} \mathrm{~N}$.

Mowing treatments were selected to simulate regimens commonly used to maintain bermudagrass golf course fairways and roughs. Regimens included $1.3 \mathrm{~cm}$ (three times/week), $2.5 \mathrm{~cm}$ (two times/week), and $5.1 \mathrm{~cm}$ (two times/week). A non-mowed control was included for comparison purposes. Mowing was conducted over a 3-month period from June to September. Plots were arranged in a randomized complete block design (a factor of proximity to irrigation) with four replications of treatments. Each experimental unit measured $1.5 \times 3.0 \mathrm{~m}$ and contained four plugs spaced $18.3 \mathrm{~cm}$ apart down the center of each plot. Mowing height in the $1.3-\mathrm{cm}$ treatment was reduced gradually during the 2 weeks before study initiation. Mowing treatments in both studies were initiated on 29 June 2009 and 30 June 2010. Plants subjected to the $1.3-\mathrm{cm}$ regimen were mowed with a walk-behind reel mower (Jacobsen WalkBehind GK 500; Jacobsen, A Textron Company, Charlotte, NC), whereas plants receiving the $2.5-$ and $5.1-\mathrm{cm}$ regimens were mowed with a walk-behind rotary mower (Honda mower Model HRR216K5VKA; American Honda Power Equipment Division, Alpharetta, GA). Irrigation (every other day) was supplied as a supplement to rainfall $(14.2 \mathrm{~cm}$ in 2009 and $25.9 \mathrm{~cm}$ in 2010) at a rate of $5.0 \mathrm{~cm} /$ week with an automated irrigation system. Plots were maintained weed-free by hand-weeding to ensure plant growth in response to mowing height was examined without competition.

Lateral plant diameter of each plant was measured at the beginning of the study and every 2 weeks thereafter through September. Two diameter measurements were taken perpendicular to each other (the first measurement was taken in the largest diameter) and averaged to obtain the reported diameter of a plant at each sampling time (Henry et al., 2007). Data from the four plugs were averaged to give estimates for each experimental unit.

No significant year-by-treatment interactions were observed, so data were pooled and subjected to analysis of variance using error partitioning appropriate to a randomized complete block design analysis in the general linear models procedure provided by SAS (SAS, Statistical Analysis Systems, 2002-08, Release 9.2; Statistical Analysis Systems Institute, Cary, NC). Measurement dates were analyzed separately. Means were separated using Fisher's protected least significant difference test at $P=0.05$.

\section{Results and Discussion}

Differences in lateral spread among mowing regimens were apparent 4 WAIT. However, plant diameter increased for all mowing regimens over the course of the trial (Table 1). Khakiweed plants subjected to the $1.3-\mathrm{cm}$ mowing regimen did not increase in diameter from Week 2 through Week 12, whereas the other two mowing regimens resulted in steady increases in plant diameter over the same time period. By 12 WAIT, non-mowed control plots measured $80.8 \mathrm{~cm}$ in diameter, whereas those maintained at $1.3 \mathrm{~cm}$ measured $55.3 \mathrm{~cm}$. Comparatively, plants subjected to the 2.5 - and $5.1-\mathrm{cm}$ mowing regimens measured 64.7 and $68.8 \mathrm{~cm}$, respectively, on the same date (Table 1).

A mowing regimen commonly used to maintain golf course fairways $(1.3 \mathrm{~cm})$ significantly reduced the lateral spread of khakiweed. Although the 2.5- and 5.1-cm mowing regimens also spread less than the non-mowed control, khakiweed was better able to withstand these mowing regimens commonly used to maintain golf course roughs, athletic fields, and home lawns. Plant growth habits and morphological characteristics may play an important role in tolerance to mowing height and frequency. Khakiweed produces a deep taproot that is protected from mowing; however, leaves produced on spreading stems may be heavily defoliated when mowed at $1.3 \mathrm{~cm}$ compared with 2.5 or $5.1 \mathrm{~cm}$. Gray and Call (1993) observed greater reductions in plants $/ \mathrm{m}^{2}$ and plant biomass of common blue violet (Viola papilionacea Prush) than Indian mockstrawberry [Duchesnea indica (Andr.) Focke] present in a tall fescue lawn in response to mowing at 4 and $6 \mathrm{~cm}$. Indian mockstrawberry produces long stolons that develop adventitious roots and generate new plants. Leaf petioles of Indian mockstrawberry vary in length, which may result in partial defoliation when mowed at lower heights. Common blue violet produces fleshy rhizomes close to the soil surface, which are protected from close mowing. However, unifoliate leaf blades of common blue violet are produced on tall, erect petioles. Mowing removes the unifoliate leaves and may result in nearly complete defoliation. The similar response of khakiweed and Indian mockstrawberry to mowing may be explained by their spreading/prostrate growth habits and asymmetrical leaf sizes.

Constant defoliation of leaf tissue may result in the depletion of carbohydrate reserves in perennial organs. Mowing khakiweed at $1.3 \mathrm{~cm}$ (three times/week) resulted in plants with the lowest diameter $(55.3 \mathrm{~cm})$ by 12 WAIT compared with 64.7 and $68.8 \mathrm{~cm}$ for the 2.5- and 5.1-cm mowing regimens (two times/week), respectively (Table 1). Summerlin et al. (2000) observed similar results when comparing the effect of mowing height and frequency on several problematic sedge species. Mowing green kyllinga at $1.3 \mathrm{~cm}$ (three times/week) reduced shoot number and plant spread $52 \%$ and $32 \%$, respectively, whereas mowing at $3.8 \mathrm{~cm}$ (one time/week) resulted in reductions of $0 \%$ and $13 \%$, respectively, compared with a nonmowed control plot (Summerlin et al., 2000). In contrast, Lowe et al. (2000) reported an increase $(200 \%$ to $500 \%)$ in green kyllinga infestation within hybrid bermudagrass when mowing height was decreased from 5.0 to $2.5 \mathrm{~cm}$, respectively, and mowing frequency was two or three times/week. Examining the response of weeds to mowing when present in a turfgrass system may act as a buffer to increased mechanical damage observed in trials that are conducted on weeds grown on bare ground. Wilen and Holt (1996) observed greater stoloniferous extension of kikuyugrass in response to no mowing or mowing at $5.0 \mathrm{~cm}$ compared with mowing at $2.5 \mathrm{~cm}$. Kikuyugrass stolons extended 88, 82, and $71 \mathrm{~cm}$ when not mowed, mowed at $5.0 \mathrm{~cm}$ (one time/week), and mowed at $2.5 \mathrm{~cm}$ (one time/week), respectively. Although kikuyugrass extension was reduced in response to mowing at $2.5 \mathrm{~cm}$, further reductions may have been observed if plants were mowed more than one time/week. Frequent biomass removal observed in other trials may likely be 
Table 1. Effect of mowing height and frequency on khakiweed (Alternanthera pungens Kunth) plant diameter $(\mathrm{cm})^{\mathrm{z}}$ in Lubbock, TX, in 2009 and 2010. ${ }^{\mathrm{y}}$

\begin{tabular}{|c|c|c|c|c|c|c|c|}
\hline \multirow{2}{*}{$\begin{array}{l}\text { Mowing ht } \\
(\mathrm{cm})\end{array}$} & \multirow{2}{*}{$\begin{array}{c}\text { Frequency } \\
\text { (times/week) }\end{array}$} & \multicolumn{6}{|c|}{ 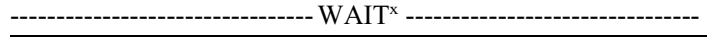 } \\
\hline & & 2 & 4 & 6 & 8 & 10 & 12 \\
\hline Non-mowed & 0 & 53.4 & 61.6 & 66.0 & 69.8 & 77.2 & 80.8 \\
\hline 5.1 & 2 & 52.0 & 59.0 & 64.1 & 66.6 & 68.4 & 68.8 \\
\hline 2.5 & 2 & 54.0 & 55.9 & 61.3 & 64.2 & 64.5 & 64.7 \\
\hline 1.3 & 3 & 55.1 & 56.9 & 56.6 & 56.8 & 55.8 & 55.3 \\
\hline $\operatorname{LSD}(P=0.05)$ & — & 6.6 & 4.8 & 4.2 & 5.8 & 4.8 & 4.9 \\
\hline
\end{tabular}

${ }^{\mathrm{z}}$ Two diameter measurements were taken perpendicular to each other (the first measurement was taken in the largest diameter) and averaged to obtain the reported diameter of a plant at each sampling time. Data from the four plugs were averaged to give estimates for each experimental unit.

${ }^{\mathrm{y}}$ Data were pooled over experiments conducted in 2009 and 2010.

${ }^{x}$ WAIT $=$ weeks after initial treatment.

LSD $=$ least significant difference.

responsible for reductions in plant spread resulting from constant reallocation of resources to leaf regeneration at the expense of stolon production.

Bermudagrass maintained at mowing heights $1.3 \mathrm{~cm}$ or less often forms a dense canopy making weed encroachment more difficult (McCarty, 1991). Higher heights of cut ( $2.5 \mathrm{~cm}$ or greater) may provide openings in the canopy that contribute to khakiweed infestation (Duble, 2001). The differential response of khakiweed to the mowing heights and frequencies used in this research may explain the predominant presence of this species in turfgrass maintained at higher mowing heights and lower frequencies in Texas (personal observation). The presence of a thick taproot with abundant carbohydrate reserves may allow khakiweed to regenerate after defoliation. Henry et al. (2007) noted that shallow rhizomes of bahiagrass were damaged by close mowing and traffic typical of a golf course fairway, whereas the deep rhizome system of dallisgrass enhanced its ability to spread vegetatively under the same environmental conditions. Although lateral spread was most negatively impacted by mowing at $1.3 \mathrm{~cm}$ (three times/week), the deep taproot of khakiweed may allow it to continue to increase in size.

Methods used in this research neglected to account for several factors pertinent to proper turfgrass management. Managed turfgrass systems (golf courses, athletic fields, and home lawns) are frequently mowed, so the degree of lateral spread observed in the non-mowed control plots is not likely to occur. In our research, khakiweed was grown on bare ground without the presence of a competing turfgrass species. Cultural practices were also conducted to alleviate competition from weeds. Lateral spread may have been further reduced if khakiweed plants were subjected to competition from bermudagrass (unpublished data), because bermudagrass varieties are bred to form dense canopies under frequent, low mowing conditions. However, responses in our research illustrate that khakiweed can persist under mowing regimens used to maintain bermudagrass fairways, roughs, and athletic fields. Although mowing alone will not control khakiweed, our findings illustrate that mowing at heights $2.5 \mathrm{~cm}$ or less can discourage lateral spread. Bradley and Hagood (2002) observed that when averaged across all herbicide treatments, two sequential mowing events conducted before herbicide application enhanced the control of mugwort (Artemisia vulgaris L.) compared with either unmowed mugwort or mugwort mowed once before herbicide application. Mislevy et al. (1999) observed $100 \%$ control of tropical soda apple (Solanum viarum Dunal) in response to two sequential mowing events followed by an application of triclopyr at $0.6 \mathrm{~kg}$ a.i./ha. Higher levels of weed control in response to sequential mowings are most likely associated with the gradual depletion in carbohydrates of perennial structures with each additional mowing event. Future research should evaluate the effects of augmented mowing practices combined with chemical applications for khakiweed control with turfgrass competition.

\section{Literature Cited}

Adams, W.A. 1980. Effects of nitrogen fertilization and cutting height on the shoot growth, nutrient removal, and turfgrass composition of an initially perennial ryegrass dominant sports turf, p. 343-350. In: Beard, J.B. (ed.). Proc. 3rd Intl Turfgrass Res. Conf., Munich, West Germany, 11-13 July 1977. ASA, CSSA, SSSA, and Int. Turfgrass Soc., Madison, WI.

Anonymous. 2009. Monument ${ }^{\mathrm{TM}}$ herbicide product label. Syngenta Crop Protection, Inc., Greensboro, NC.

Bradley, K.W. and E.S. Hagood, Jr. 2002. Influence of sequential herbicide treatment, application timing, and mowing on mugwort (Artemisia vulgaris) control. Weed Technol. $16: 346-352$.

Busey, P. 2003. Cultural management of weeds in turfgrass: A review. Crop Sci. 43:1899-1911.

Bush, E.W., A.D. Owings, D.P. Shepard, and J.N. McCrimmons. 2000. Mowing height and nitrogen rate affect turf quality and vegetative growth of common carpetgrass. HortScience 35:760-762.

Dernoeden, P.H., M.J. Carroll, and J.M. Krouse. 1993. Weed management and tall fescue quality as influenced by mowing, nitrogen, and herbicides. Crop Sci. 33:1055-1061.

Duble, R.L. 2001. Turfgrass maintenance proment and use in the southern zone. 2nd Ed. Texas A\&M University Press, TX. grams, p. 291. In: Turfgrasses: Their manage-
Gray, E. and N.M. Call. 1993. Fertilization and mowing on persistence of Indian mockstrawberry (Duchesnea indica) and common blue violet (Viola papilionacea) in a tall fescue (Festuca arundinacea) lawn. Weed Sci. 41:548-550.

Henry, G.M., M.G. Burton, and F.H. Yelverton. 2007. Effect of mowing height on lateral spread and rhizome growth of troublesome Paspalum species. Weed Sci. 55:486-490.

Hephner, A.J., T. Cooper, L.L. Beck, and G.M. Henry. 2012. Sequential postemergence applications for the control of khakiweed in bermudagrass turf. HortScience 47:434-436.

Hoyle, J.A. 2009. Effect of mowing height in turfgrass systems on pest incidence. MS thesis, North Carolina State University, NC.

Jagschitz, J.A. and J.S. Ebdon. 1985. Influence of mowing, fertilizer and herbicide on crabgrass, p. 699-704. In: Lemaire, F. (ed.). Infestation in red fescue turf. Proc. 5th Inter. Turf. Res. Conf., Avignon, France.

Kopec, D.M., J.J. Gilbert, and M. Pessarakli. 2004. Penoxsulam as a potential post-emergence for khakiweed (Alternanthera pungens). University of Arizona College of Agriculture Turfgrass and Ornamental Research Report. $<\mathrm{http} / /$ cals.arizona.edu/pubs/crops/az1359/>.

Lowe, D.B., T. Whitwell, L.B. McCarty, and W.C. Bridges. 2000. Mowing and nitrogen influence green kyllinga (Kyllinga brevifolia) in Tifway bermudagrass (Cynodon dactylon $\times C$. transvaalensis) turf. Weed Technol. 14:471-475.

McCarty, L.B. 1991. Goosegrass (Eleusine indica) control in bermudagrass (Cynodon spp.) turf with diclofop. Weed Sci. 39:255-261.

McCarty, L.B., J.Q. Everest, D.W. Hall, T.R. Murphy, and F. Yelverton. 2008. Color atlas of turfgrass weeds. 2nd Ed. Ann Arbor Press, Chelsea, MI. p. 432.

Mislevy, P., J.J. Mullahey, and F.G. Martin. 1999. Preherbicide mowing and herbicide rate on tropical soda apple (Solanum viarum) control. Weed Technol. 13:172-175.

Parsons, W.T. and E.G. Cuthbertson. 2001. Khakiweed, p. 158-159. In: Noxious weeds of Australia. CSIRO Pub., Collingwood, Victoria, Australia.

Sholedice, F. and M. Renz. 2006. Khakiweed. New Mexico State Univ. O \& T Guide W-8 Cooperative Extension Service. College of Agric. \& Home Economics. Las Cruces, NM. <http://aces. nmsu.edu/ces/plantclinic/documents/khakiweedw-8.pdf $>$.

Stoll, P., P. Egli, and B. Schmid. 1998. Plant foraging and rhizome growth patterns of Solidago altissima in response to mowing and fertilizer application. J. Ecol. 86:341-354.

Summerlin, J.R., Jr., H.D. Coble, and F.H. Yelverton. 2000. Effect of mowing on perennial sedges. Weed Sci. 48:501-507.

Umeda, K. 2008. Evaluation of herbicides for khakiweed control. Turfgrass, Landscape and Urban IPM Research Summary. p. 25-29.

Umeda, K. and G. Towers. 2004. Evaluation and comparison of spotlight* herbicide combinations for khakiweed control in turf. In: University of Arizona College of Agriculture 2004 Turfgrass and Ornamental Research Report. $<$ http://cals.arizona.edu/pubs/crops/az13559/>.

Voigt, T.B., T.W. Fermanian, and J.E. Haley. 2001. Influence of mowing and nitrogen fertility on tall fescue turf. Intl. Turfgrass Soc. Res. J. 9:953-956

Wilen, C.A. and J.S. Holt. 1996. Spatial growth of kikuyugrass (Pennisetum clandestinum). Weed Sci. 44:323-330. 